\title{
Spatio-temporal variability in the deposition of beach-cast kelp (wrack) and inter-specific differences in degradation rates
}

\author{
Abby R. Gilson ${ }^{1,5, *}$, Dan A. Smale ${ }^{2}$, Michael T. Burrows ${ }^{3}$, Nessa E. O'Connor ${ }^{1,4}$ \\ ${ }^{1}$ School of Biological Sciences, Institute of Global Food Security, Queen's University Belfast, Belfast BT9 5AJ, UK \\ ${ }^{2}$ Marine Biological Association of the UK, Citadel Hill, Plymouth PL1 2PB, UK \\ ${ }^{3}$ Scottish Association for Marine Science, Scottish Marine Institute, Oban, Argyll PA37 1QA, UK \\ ${ }^{4}$ School of Natural Sciences, Zoology Building, Trinity College Dublin, Dublin 2, Ireland \\ ${ }^{5}$ Present address: Department of Zoology and Entomology, Rhodes University, PO Box 94, Grahamstown 6140, South Africa
}

\begin{abstract}
Coastal habitats dominated by marine macroalgae typically exhibit high rates of primary productivity and play a key role in local and regional carbon cycles and stores. In temperate regions, large brown algae (i.e. kelps and fucoids) contribute significantly to macroalgal primary production, most of which is exported from source habitats as detritus. The ultimate fate of this detritus and the processes controlling detrital pathways into food webs and carbon cycles remain poorly understood. Based on field surveys, we quantified the biomass of kelp-derived detritus (wrack) at sandy and pebble-dominated shores in Ireland and conducted a manipulative field experiment to test for inter-specific differences in detritus degradation rates and the effect of macroinvertebrate detritivores. Overall, accumulated wrack biomass was similar on all shores but varied temporally depending on habitat type. Degradation rates and the nutritional (C:N) and chemical (polyphenol concentrations) properties differed among kelp species. Interestingly, exclusion of macroinvertebrate detritivores did not affect kelp degradation rates, C:N ratios or polyphenol content. Our findings show that rates of macroalgal breakdown differ among kelp species and that, in contrast to other aquatic systems, macroinvertebrates appear to play a very limited role in the breakdown of these marine detrital subsidies, suggesting a key role for meiofauna and microbes in detritus processing. Increasing recognition for the role of detritus in coastal food webs and carbon cycles warrants a better understanding of the mechanisms underpinning degradation rates.
\end{abstract}

KEY WORDS: Degradation - Detritivores - Detritus - Ecosystem functioning - Food web · Macrophytes $\cdot$ Nutrient cycling

\section{INTRODUCTION}

Detrital subsidies play a key role determining trophic structures by increasing levels of diversity and supporting greater secondary biomass (Polis et al. 1997, Moore et al. 2004, Gilson et al. 2021). Both theoretical and experimental studies have demonstrated how detrital subsidies affect energy and

${ }^{*}$ Corresponding author: a.gilson@ru.ac.za nutrient transfer, consumer dynamics and food web stability (Bustamante et al. 1995, Dugan et al. 2003, Loreau et al. 2003, Colombini et al. 2009, Marleau et al. 2010, Barnes et al. 2018). Despite this importance, many detrital pathways remain unresolved and recent studies are only just beginning to understand the transformation (Elliott Smith et al. 2018, FilbeeDexter et al. 2020), transport (Wernberg \& Filbee- 
Dexter 2018) and export of detritus (Filbee-Dexter et al. 2019, 2020, Pedersen et al. 2020) and the potential impacts of environmental change on coastal carbon cycling. Much progress has been made in freshwater systems, however, in which consumer-resource interactions can dominate food web dynamics and are often more influential than interactions within trophic levels (Dangles \& Malmqvist 2004, Woodward 2009, Little \& Altermatt 2018). In highly connected systems, such as coastal marine habitats, potential impacts on donor communities can also have significant consequences for recipient communities, placing further emphasis on the importance of empirical studies to resolve detrital pathways (Hori 2008, FilbeeDexter \& Scheibling 2012, Krumhansl \& Scheibling 2012a).

Kelp-dominated habitats are widely distributed across low intertidal and shallow subtidal reefs along temperate, Arctic and sub-polar coastlines and have strong linkages to adjacent ecosystems (Krumhansl \& Scheibling 2012). Kelps (Order Laminariales) typically exhibit high primary productivity, which in turn supports elevated levels of secondary production and underpins the provision of ecosystem goods and services worth billions of dollars per year (Bennett et al. 2016, Blamey \& Bolton 2018). As ecosystem engineers, kelps provide a structurally complex, biogenic habitat that creates biodiversity hotspots supporting many commercially important species (Smale et al. 2013, Teagle et al. 2017). It is estimated that $80 \%$ of kelp enters the food web through detrital pathways following partial or whole dislodgement (Krumhansl \& Scheibling 2012), reaching rocky shores (Bustamante et al. 1995), sandy beaches (Gómez et al. 2013), vegetated sediments (Wernberg et al. 2006, Hyndes et al. 2012), intermediate shallow nearshore and mesophotic depths (Vanderklift \& Wernberg 2008, Britton-Simmons et al. 2012) and the deep sea (Filbee-Dexter et al. 2018). Little is known regarding the degradation process, including specific rates of degradation despite the widespread occurrence of these detrital kelp subsidies, particularly under differing abiotic conditions, and the mechanisms by which nutrients are recycled (Legge et al. 2020). To date, macrophyte-derived production is not included explicitly in most marine ecosystem models and few field measurements have verified the contribution of these processes to components of the carbon cycle (Queirós et al. 2019). Refining coastal carbon fluxes with direct observational studies is critical to enabling estimates and predictions about how these coastal systems will respond to environmental change.
Degradation rates can be affected by local environmental factors, such as temperature and solar radiation, and other physical processes including wave action and mechanical resuspension (Newell et al. 1985, Ståhlberg et al. 2006). The nutritional quality of detritus has also been shown to play a role, with differences in the nutritional (C:N ratio) and chemical (secondary metabolites) content significantly affecting detrital breakdown through changes to microbial activity (Krumhansl \& Scheibling 2012). However, information describing how inter-specific variation among dominant kelp species affects rates of degradation and nutrient cycling is limited (Van Alstyne et al. 1999, Norderhaug et al. 2003, 2006), and the implications for rates of transport, burial and longterm carbon sequestration capacity are unknown (Krause-Jensen et al. 2018, Legge et al. 2020).

Invertebrate detritivores are thought to contribute significantly to coastal carbon and nutrient cycles through the breakdown and recycling of organic matter (Raffaelli et al. 2003, Godbold et al. 2009, Bruder et al. 2014). It has also been shown that microbial degradation must first increase the nutritional value and palatability of kelp-derived detritus by reducing $\mathrm{C}: \mathrm{N}$ ratios and levels of phenolic compounds before it is available for fragmentation and consumption by higher trophic levels (Norderhaug et al. 2003, Krumhansl \& Scheibling 2012). These detrital pathways are largely unresolved, however, with complex interactions between litter composition, detritivore assemblage composition and environmental conditions yet to be disentangled (García-Palacios et al. 2016). For example, applying biodiversityecosystem functioning theory, we may expect to see faster rates of detrital breakdown and nutrient cycling linked to a greater diversity of species of kelp-derived detritus, driven by complementarity effects (Loreau 2001, Godbold et al. 2009, Tilman et al. 2014). These diversity effects on leaf litter breakdown have been extensively shown in freshwater systems where allochthonous detrital subsidies are a significant trophic pathway (Woodward 2009, Kominoski et al. 2010, García-Palacios et al. 2016), while comparatively little is known about the ecology of detrital breakdown in marine systems.

To address this knowledge gap, we quantified the biomass of kelp-derived detritus deposited on intertidal shores (hereafter termed 'wrack') and tested whether this differed between habitats (sandy and pebble-dominated shores) and was consistent through time (over 22 survey months). We also conducted field experiments to test for differences in degradation rates, $\mathrm{C}: \mathrm{N}$ ratios and polyphenol content 
of 4 kelp species common in the NE Atlantic (Laminaria hyperborea, L. digitata, Saccharina latissima and Saccorhiza polyschides). In addition, we tested experimentally whether degradation rates of mixtures of co-occurring kelp species were faster than rates of mono-specific kelp patches. Finally, we characterised invertebrate detritivore assemblages associated with each kelp species and tested whether degradation was faster in the presence of these detritivores (and whether this was linked to reduced C:N ratios and polyphenol content in the degrading kelp).

\section{MATERIALS AND METHODS}

\subsection{Field sites}

Surveys of accumulated wrack were carried out at 2 pebble-dominated (Glasshaugh Bay $55.264^{\circ} \mathrm{N}$, $7.675^{\circ} \mathrm{W}$; Ballywhoriskey $55.250^{\circ} \mathrm{N}, 7.745^{\circ} \mathrm{W}$ ) and 2 sandy (Ballywhoriskey Pier $55.248^{\circ} \mathrm{N}, 7.741^{\circ} \mathrm{W}$; White Shore $55.253^{\circ} \mathrm{N}, 7.69^{\circ} \mathrm{W}$ ) sites in County Donegal, NW Ireland (Fig. 1). These sites are typical of pebble and sandy shores of the NE Atlantic region, where accumulation of wrack is a common feature, and were selected randomly from a larger pool of potential sites based on substrata, aspect and accessibility. Sites were paired based on proximity and aspect to avoid any confounding effects of prevailing wind direction, with 1 pebble and 1 sandy site facing north and the remaining 2 facing northwest (Fig. 1). All sites have a maximum tidal range of approximately $3.5-4.5 \mathrm{~m}$ (Cooper et al. 2004) and were 450$600 \mathrm{~m}$ in length between 2 headlands on either side of each beach. Pebble sites were more exposed than sandy sites, which was reflected in the composition of the substratum and the topography of the shore. Sandy sites were composed of fine sand (mean grain size $0.125-0.25 \mathrm{~mm}$ ) and were backed by sand dune systems owing to the high frequency of westerly gales (O'Connor et al. 2007). Pebble sites were characterised by wellrounded cobbles $(\sim-15 \mathrm{~cm}$ in diameter) and large granite boulders at the top of the shore backed by coastal vegetation and grassland. No obvious urbanisation, beach nourishment activities or wrack removal were observed at any site.

\subsection{Quantification of kelp-derived detritus}

To test for differences in wrack accumulation between pebble and sandy sites, surveys were conducted monthly between May 2016 and February 2018 at each site (Ballywhoriskey, Glassaugh Bay, Ballywhoriskey Pier and White Shore). At all 4 sites, $4 \times 20 \mathrm{~m}$ transects perpendicular to the shore were placed at least $20 \mathrm{~m}$ apart, extending from the lowest line of coastal vegetation or sand dune. Along each transect, 10 plots located at $2 \mathrm{~m}$ intervals were established. At each plot, 3 quadrats $\left(0.5 \mathrm{~m}^{2}\right)$ were thrown randomly, and wrack volume was estimated $(\mathrm{n}=30$ quadrats per transect). Within each quadrat, total percentage cover of wrack was estimated visually and the depth was recorded by randomly inserting a measuring stick 3 times into the wrack until the substratum was reached. Wrack volume was then estimated by multiplying the area of wrack cover by the mean depth. Volume estimates were converted to biomass using a density factor of $0.532 \mathrm{~kg} \mathrm{l}^{-1}$, obtained by weighing wrack from all levels of the shore in a 101 bucket $(n=50)$. Care was taken to include wrack at all stages of degradation to account for any biomass change that may occur throughout the degradation process. Although it was difficult to identify which macroalgal species contributed to beach-cast wrack, it was evident from the appearance of stipes and fronds that Laminaria hyperborea and $L$. digitata were the greatest contributors to

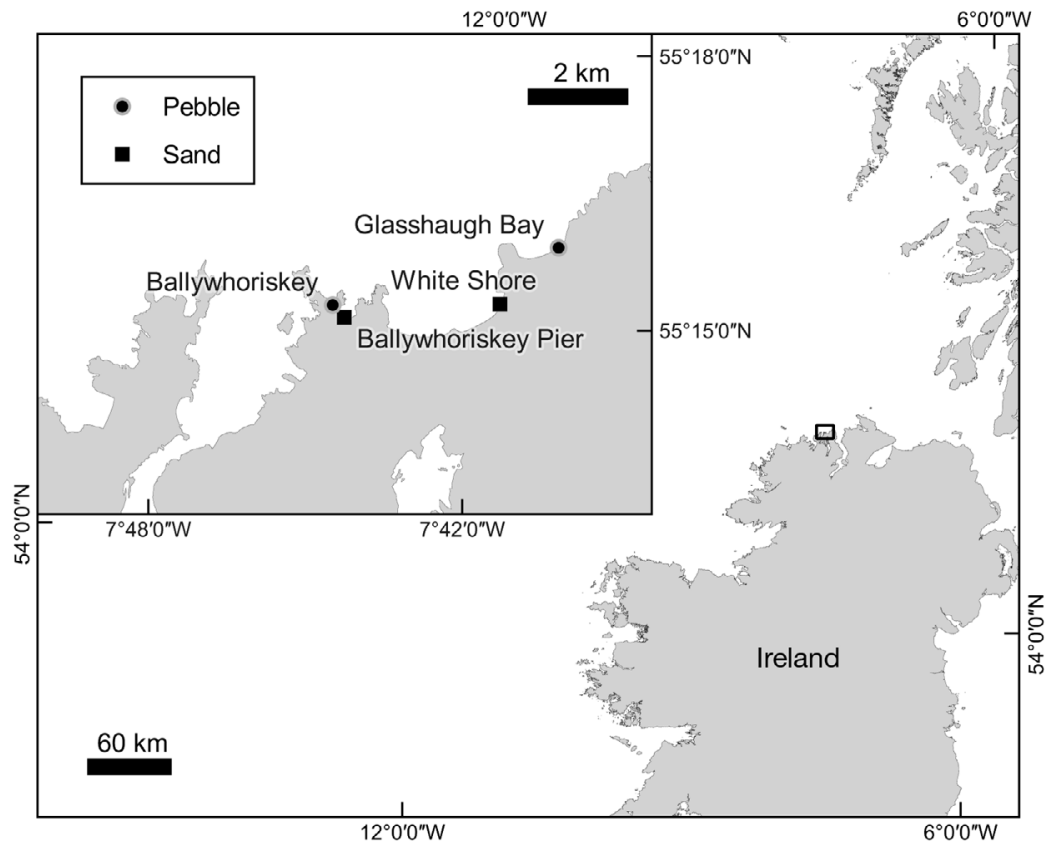

Fig. 1. Field sites at pebble (Ballywhoriskey and Glassaugh Bay) and sandy (Ballywhoriskey Pier and White Shore) shores in Co. Donegal, Ireland 
wrack biomass, particularly above the mid-shore level, although other kelp species were also present. Fucoids were also moderately abundant, and red and green macroalgae were present in small quantities. Data pertaining to environmental variables that may affect the process of wrack deposition (wave height, wind speed and sea temperature) were also obtained from the nearest wave buoy (Marine Institute M5 station, Co. Donegal) or weather station (UK Met Office Malin Head station, Co. Donegal). Monthly mean wave height $(\mathrm{m})$, wind speed (knots) and temperature $\left({ }^{\circ} \mathrm{C}\right)$ were estimated for each month between May 2016 and February 2018.

\subsection{Differences in degradation rates of kelp-derived detritus}

Kelps occupy the low intertidal and subtidal rocky reefs of Ireland where 5 dominant species co-exist (Smale et al. 2013, Schoenrock et al. 2020). Highenergy subtidal habitats are dominated by the canopy-forming L. hyperborea down to a depth of up to $\sim 30 \mathrm{~m}$ (Smale et al. 2013 and references therein), while intertidal and shallow, subtidal, wave-exposed reef areas are dominated by L. digitata. Saccharina latissima may also be locally abundant and dominant but is replaced by Alaria esculenta under more waveexposed conditions, and the pseudo-annual 'kelp' Saccorhiza polyschides (taxonomically speaking a member of the Tilopteridales) is patchily distributed throughout intertidal and subtidal habitats owing to its opportunistic nature (Smale et al. 2013). These kelp species differ in several functional traits (e.g. life histories and growth periods) and physical properties that may significantly affect rates of detrital breakdown and detritivore consumption, including nutritional (C:N) and biochemical profile (polyphenolics; e.g. Van Alstyne et al. 1999, Norderhaug et al. 2003, Schiener et al. 2015, Stévant et al. 2017, Epstein et al. 2019). During the wrack surveys described above, these kelps were found to co-occur in beach-cast wrack, with whole or fragmented individuals observed.

To test for differences in the degradation rates of common kelp species, an experiment was carried out at 2 pebble shores (Fig. 1). The experiment ran for 4 wk starting in September in 2017 and was repeated in September 2018. The experimental design included site (random, 2 levels) and experimental treatments comprised of monocultures or mixtures of 4 common kelp species (5 fixed levels: L. hyperborea, L. digitata, S. latissima, S. poly- schides and a mixture or 'polyculture' of all 4 kelp species each present in similar biomass). Nylon mesh bags with a known wet biomass of kelpderived detritus were deployed high on the shore at both sites as determined by the position of the wrack line at each site $(n=5$ bags per treatment per site). Each bag was allocated randomly to a position along a pre-determined transect that ran parallel to the shore, and bags were placed at least $1 \mathrm{~m}$ apart from one another. All bags contained a total of $600 \mathrm{~g}$ (fresh weight) of kelp, which was based on their typical biomass in $0.5 \mathrm{~m}^{2}$ quadrats averaged over the 3 mo preceding each experiment from wrack biomass surveys at pebble sites $(\mathrm{n}=180)$. Samples were taken from the basal part of the blade tissue of each kelp species to avoid confounding any differences in chemical or nutritional content between different morphological components (i.e. holdfast, stipe, frond) and to standardise sampling among species. To identify the role of detritivores in kelp degradation rates, detritivore access was manipulated and comprised 2 levels (2 fixed levels: access, exclusion). Bags were constructed from $200 \mu \mathrm{m}$ mesh to ensure exclusion of all meso- and macroinvertebrate detritivores. Access treatments were created by making 6 cuts (each $5 \mathrm{~cm}$ long) randomly in each bag. To ensure detritus was not lost through access holes, holes in the outside bag were cut in different places relative to holes in the $200 \mu \mathrm{m}$ mesh. After a $4 \mathrm{wk}$ period, bags were recovered from the shore, placed in plastic bags to ensure detritivore communities remained intact and transported back to the lab with cool blocks to prevent any further degradation. For each bag, wet biomass, carbon:nitrogen $(\mathrm{C}: \mathrm{N})$ ratio and polyphenol content of the remaining kelp detritus, and detritivore assemblage structure were quantified $(\mathrm{n}=5)$. Polycultures were not analysed for $\mathrm{C}: \mathrm{N}$ ratios or polyphenol content, as degraded material could no longer be distinguished between species, and it was not possible to get reliable samples of an individual species, or a sample containing all species, from each bag.

To quantify the nutritional and chemical content of each kelp species after degradation, a sub-sample of macroalgal material was taken from each bag containing a monoculture. Samples were freeze-dried to constant mass and ground using a pestle and mortar into a homogeneous powder. Sub-samples (200 mg) were then placed in tin capsules and mounted in an automatic carousel to be analysed for total C and $\mathrm{N}$ content by means of a Thermo Scientific ${ }^{\mathrm{TM}}$ DELTA 
V TM Isotope Ratio Mass Spectrometer coupled to a Thermo Flash 1112 Elemental Analyser (Epstein et al. 2019) and C:N ratios were calculated. A further $200 \mathrm{mg}$ sub-sample was then extracted in the dark in $2 \mathrm{ml}$ of an acetonitrile/water/formic acid (59:49.8:0.2, $\mathrm{v} \mathrm{v}^{-1}$ ) solvent mix at room temperature under rotary action for $1 \mathrm{~h}$. Each individual sample underwent the extraction process 3 times to ensure all possible material was extracted. At the end of each extraction phase, vials were centrifuged for $2 \mathrm{~min}$ at $1147 \times g$ and supernatant collected in a $10 \mathrm{ml}$ volumetric flask, with final volume adjustments using fresh solvent to $10 \mathrm{ml}$. Using gallic acid as a standard, a Folin Ciocalteau colourimetric method (Waterhouse 2001) was then applied and absorbance was read at $700 \mathrm{~nm}$ on a UV 160A spectrophotometer to determine total phenolic content. Values were expressed as \% polyphenol content of dried algal biomass. Although C:N ratios and polyphenol content were quantified after degradation, fresh samples were not analysed prior to degradation and comparisons between fresh and degraded kelp cannot be made. We were therefore unable to test whether nutritional and chemical content are drivers of degradation rates or a response to the degradation process. Rather, differences in nutritional and chemical content between species were explored as a possible mechanism relating to detrital breakdown.

To test whether different kelp detritus treatments (monocultures and mixture) supported different detritivore assemblages, the remaining detrital material in each bag at the end of the experiment was sieved through a $500 \mu \mathrm{m}$ mesh. All detritivores were then collected and stored in a $90 \%$ ethanol solution. Exclusion bags were also checked for detritivores to ensure the exclusion treatment was effective, and statistical analysis identified a mean of $<1$ ind. bag $^{-1}$. Taxonomic richness was estimated by identifying organisms to family level and abundance estimated by counting individual heads (Eleftheriou \& Holme 1984).

\subsection{Data analysis}

For the observational survey data, we tested for the effects of habitat (fixed effect, 2 levels: sand, pebble), sampling period (fixed effect, 22 levels: June 2016-February 2018) and site (random and nested in habitat, 4 levels: Ballywhoriskey, Glassaugh Bay, Ballywhoriskey Pier and White Shore) on wrack biomass using linear mixed-effects models (LMEs) fitted by maximum likelihood with the package 'Ime4' (Zuur et al. 2009). An autocorrelation term was also added to the model to test for dependence of multiple sampling points in the time series, but no evidence of autocorrelation was found. For the manipulation experiment, we tested for the effects of experimental kelp treatment (fixed effect, 5 levels), detritivore access (fixed effect, 2 levels), year (random effect, 2 levels) and site (random effect, 2 levels) on biomass loss per day (as a proxy for detrital breakdown), C:N ratio and polyphenol content of kelp-derived detritus. Here site and year were treated as random factors in the model because we did not make explicit predictions based on different levels of either factor; thus, we were only interested in incorporating spatial variance to test for generality of results. Although random factors with fewer than 5 levels may produce less accurate variance estimates, this method was chosen to prevent biased coefficients (Harrison et al. 2018). LMEs were also used to test for the effects of kelp treatment (fixed effect, 5 levels), year (random effect, 2 levels) and site (random effect, 2 levels) on differences in total (meso- and macroinvertebrate) detritivore taxonomic richness. Where model assumptions were met, ANOVA was used to obtain $\chi^{2}$ and p-values (package 'car'; Fox \& Weisberg 2011). Where p-values were significant, Tukey HSD adjusted pairwise comparisons using least-square means were used for post hoc comparisons (package 'Ismeans'; Lenth 2018). Residuals were visually inspected and QQ plots used to check assumptions of normality and homogeneity of variance (Zuur et al. 2009). Where residuals did not meet model assumptions (i.e. C:N ratio), data were log-transformed prior to analysis. All univariate analyses were conducted using R version 3.3.4 (R Development Core Team 2017).

Permutational multivariate ANOVA (PERMANOVA) was used to test for the effect of kelp treatment (fixed effect, 5 levels: L. hyperborea, L. digitata, S. latissima, S. polyschides and a mixture or 'polyculture' of all kelp species each present in similar biomass), year (random effect, 2 levels: 2017, 2018) and site (random, 2 levels) on detritivore assemblage structure. Bray-Curtis dissimilarity matrices were generated from fourth-root transformed abundance data, and main terms and their interactions were tested with 9999 permutations (Clarke et al. 2014). The results of all PERMANOVA tests were not significant and therefore no further multivariate analysis was undertaken. Analyses were conducted in PRIMER (v7.0) software (Clarke \& Gorley 2015) with the PERMANOVA add-on. 


\section{RESULTS}

\subsection{Quantification of kelp-derived detritus}

The biomass of wrack accumulations varied markedly among survey months, with several peaks in biomass observed at both habitat types (Fig. 2). There was a significant interaction between habitat and sampling period on wrack biomass, indicating differences in wrack biomass between habitats but only during certain months (habitat $\times$ sampling period: $\left.\chi_{1,20}^{2}=746.39_{i} \mathrm{p}<0.001\right)$. At pebble sites, biomass $( \pm \mathrm{SE})$ peaked in September in both 2016 and 2017 (4.7 \pm 0.7 and $6.7 \pm 0.7 \mathrm{~kg} \mathrm{~m}^{-3}$, respectively) and was higher than any peaks seen at sandy sites (Fig. 2). Wrack biomass at sandy sites peaked later in the year in Novem-
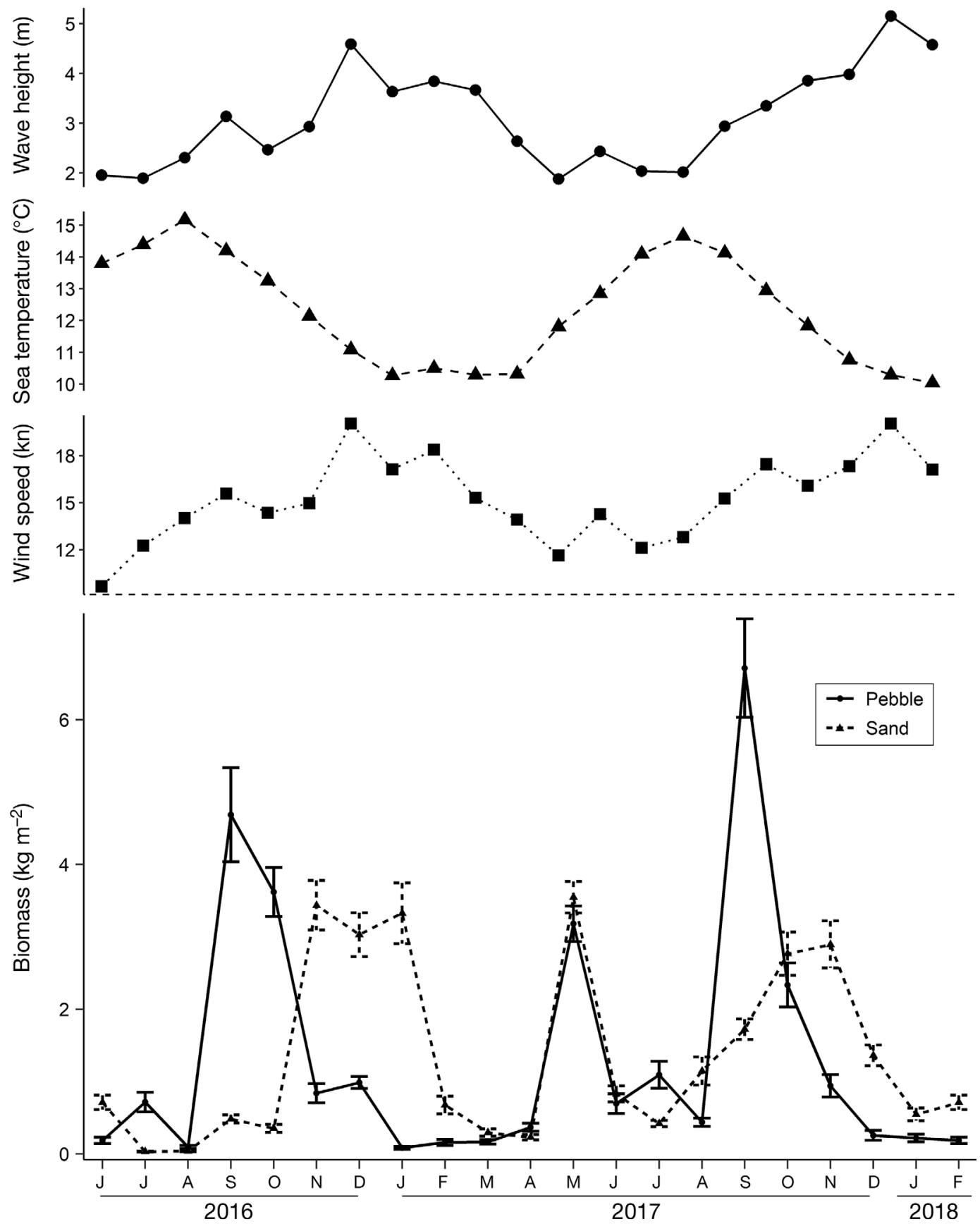

Fig. 2. (a) Monthly mean wave height (m), sea temperature $\left({ }^{\circ} \mathrm{C}\right)$ and wind speed (knots) along the NW coastline of Co. Donegal, Ireland, and (b) monthly wrack biomass $\left( \pm \mathrm{SE}, \mathrm{kg} \mathrm{m}^{-2}\right)$ on pebble (Ballywhoriskey and Glassaugh Bay) and sandy (Ballywhoriskey Pier and White Shore) beaches (see Fig. 1); $\mathrm{n}=30$ 
ber of 2016 and 2017 (3.4 \pm 0.3 and $2.9 \pm 0.3 \mathrm{~kg} \mathrm{~m}^{-3}$, respectively), but wrack biomass also peaked in May at both habitats (pebble: $3.2 \pm 0.2 \mathrm{~kg} \mathrm{~m}^{-3}$; sand: $3.5 \pm$ $0.2 \mathrm{~kg} \mathrm{~m}^{-3}$ ).

Average wind speed and wave height during the experiment period followed a seasonal pattern in which both were greatest during winter months (December and January) and lowest during the summer (June and July), and the average monthly sea temperature peaked during Autumn (August and September; Fig. 2).

\subsection{Differences in degradation rates of kelp-derived detritus}

Degradation rates of wrack differed among kelp species $\left(\chi_{1,4}^{2}=905.424 ; \mathrm{p}<0.001\right.$; Fig. 3a), but the presence of detritivores had no effect. Post hoc tests showed that Laminaria digitata degraded the fastest, followed by polyculture, then Saccharina latissima, and with both L. hyperborea and Saccorhiza polyschides degrading at the slowest rate (Fig. 3a).
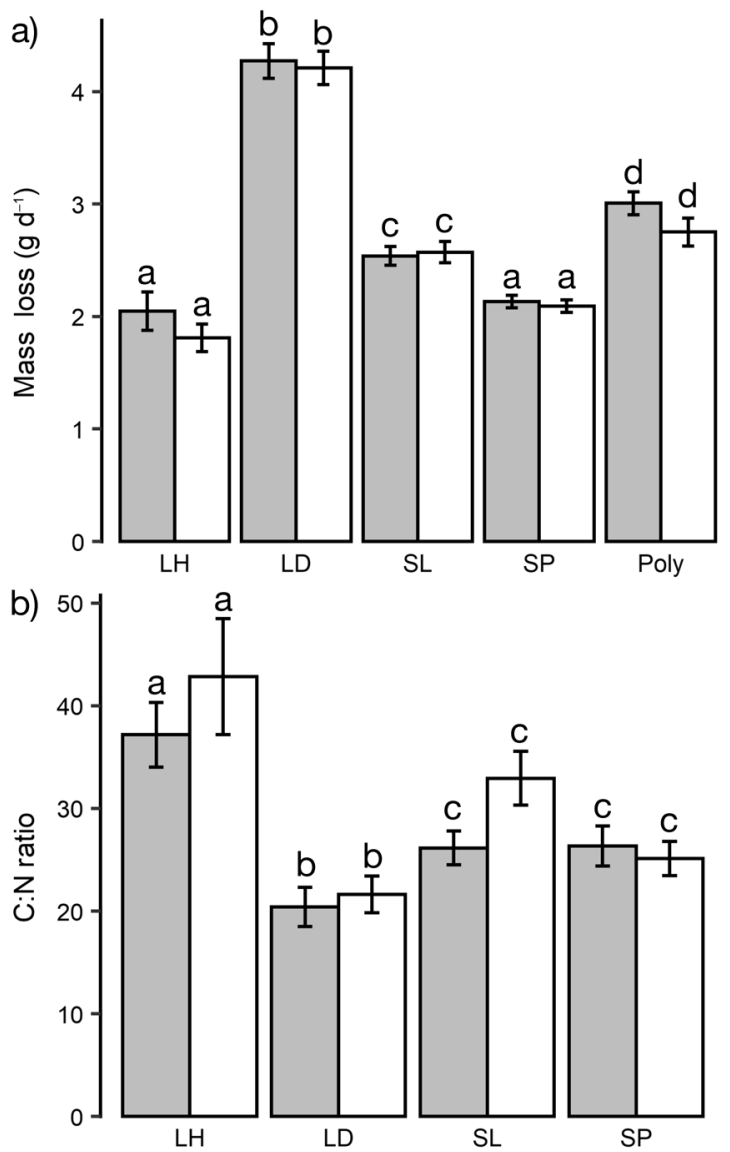

$\mathrm{C}: \mathrm{N}$ ratios differed among kelp species $\left(\chi_{1,3}^{2}=\right.$ 59.480; p $<0.001)$. Post hoc tests showed that $L$. hyperborea had a significantly higher $\mathrm{C}: \mathrm{N}$ ratio than $S$. latissima and $S$. polyschides, both with similar but greater C:N ratios than L. digitata (Fig. 3b). Polyphenol content also differed among kelp species $\left(\chi_{1,3}^{2}=\right.$ 22.745 ; p $<0.001)$, with $S$. polyschides having significantly lower polyphenol content than L. hyperborea and $L$. digitata but similar to $S$. latissima (post hoc tests, Fig. 3c). No significant effect of detritivore access on $\mathrm{C}: \mathrm{N}$ ratios or polyphenol content was identified (see Table A1 in the Appendix for summary statistics).

\subsection{Detritivore assemblage structure}

Overall, one sub-order and 16 detritivore families were identified, representing both marine and terrestrial taxa (Table 1). Detritivore taxon richness did not differ among kelp treatments $\left(\chi_{1,4}^{2}=9.407 ; \mathrm{p}=\right.$ 0.06; Fig. 4a), and PERMANOVA did not identify any differences in detritivore assemblage structure associated with different kelp species (pseudo- $F_{1,4}=$

Fig. 3. Mean ( $\pm \mathrm{SE}$ ) (a) mass loss $\left(\mathrm{g} \mathrm{d}^{-1}\right)$, (b) carbon:nitrogen $(\mathrm{C}: \mathrm{N})$ ratios and $(\mathrm{c})$ polyphenol concentration (\%) of experimentally degraded seaweed in the presence ('access') and absence ('exclusion') of detritivores on pebble shores (Ballywhoriskey and Glassaugh Bay) in Co. Donegal, Ireland. $\mathrm{n}=$ 16-20. LH: Laminaria hyperborea; LD: Laminaria digitata; SL: Saccharina latissima; SP: Saccorhiza polyschides; Poly: polyculture of all kelp species. Differing lowercase letters between groups indicate that they are statistically distinguishable based on post hoc tests (Tukey HSD, p < 0.05)

\section{Access $\square$ Exclusion}

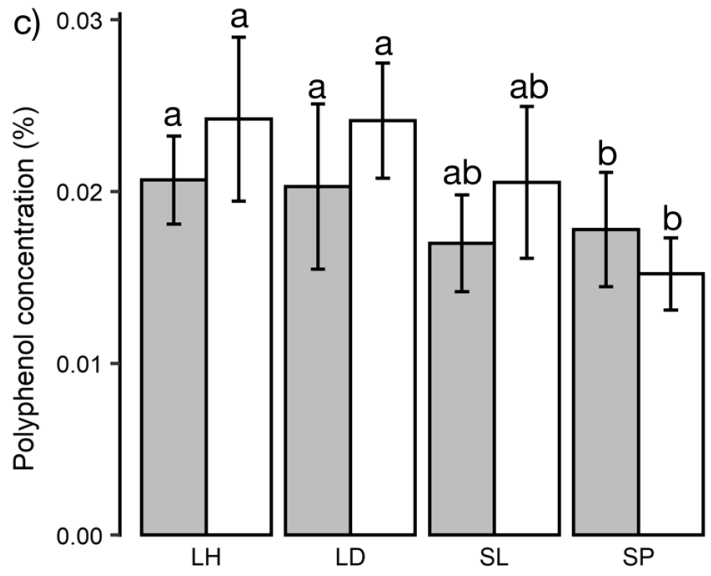


Table 1. Detritivore families found in bags of degraded kelpderived detritus at 2 pebble shores (Ballywhoriskey and Glassaugh Bay) in Co. Donegal, Ireland. LH: Laminaria hyperborea; LD: Laminaria digitata; SL: Saccharina latissima; SP: Saccorhiza polyschides; Poly: polyculture of all kelp species. (+) indicates species presence, $(-)$ indicates species absence

\begin{tabular}{lccccc|}
\hline Family & LH & LD & SL & SP & Poly \\
\hline Anisolabidae & + & - & + & + & + \\
Brachycera larvae & + & + & + & + & + \\
Brachycera pupae & + & + & + & + & + \\
Caprellidae & - & - & + & - & - \\
Carabidae & - & - & - & + & - \\
Carabidae larvae & - & - & + & - & - \\
Coelopidae & + & + & + & + & + \\
Enchytraeidae & + & + & + & + & + \\
Hydrophilidae & + & + & + & + & + \\
Hypogastruridae & + & - & + & + & + \\
Idoteidae & - & - & - & - & + \\
Ligiidae & + & + & + & + & + \\
Lycosidae & - & - & - & + & + \\
Muscidae & + & + & + & + & + \\
Pisauridae & - & - & - & + & - \\
Ptiliidae & + & + & + & + & + \\
Staphylinidae & + & + & + & + & + \\
Talitridae & + & + & + & + & + \\
Tipulidae & - & - & - & + & - \\
\hline
\end{tabular}
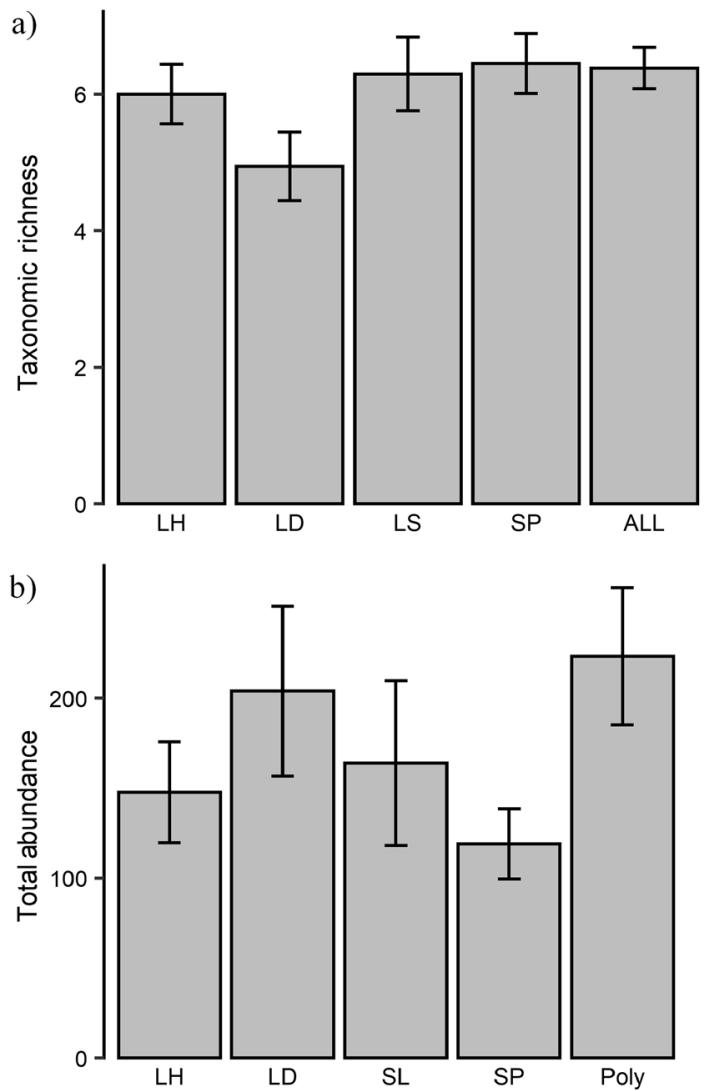

1.1246; $\mathrm{p}=0.40$ ). Total detritivore abundance did not differ between kelp species (Fig. 4b), but detritivore assemblages were dominated by Brachycera larvae and talitrid amphipods. The abundance of Brachycera larvae differed among kelp species $\left(\chi_{1,4}^{2}=13.54\right.$; $\mathrm{p}<0.001)$, with greater abundance in $L$. digitata treatments compared to $S$. polyschides, but no difference among the remaining species (Fig. 4c). The abundance of talitrid amphipods did not differ among kelp treatments owing to high variability, but abundances in L. digitata treatments were generally lower compared to all other kelp species (Fig. 4d).

\section{DISCUSSION}

Characterising the degradation pathways of detrital subsidies is essential to understand carbon and nutrient cycling in coastal systems. We found that rates of kelp detritus (wrack) accumulation differed throughout the year and between habitat types. Kelp degradation rates differed among species and generally reflected differences in $\mathrm{C}: \mathrm{N}$ ratios. Some differences in polyphenol content were identified, but
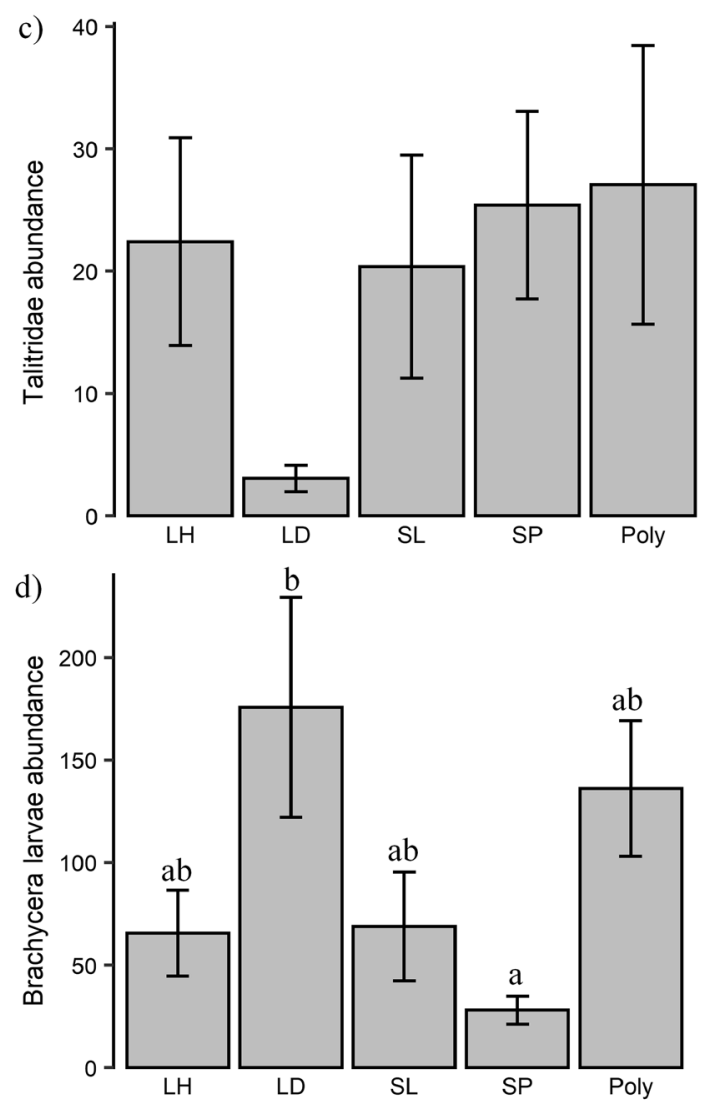

Fig. 4. Mean $( \pm \mathrm{SE})(\mathrm{a})$ taxonomic richness and abundances of (b) detritivores, (c) Talitridae and (d) Brachycera larvae recorded within bags of experimentally degraded seaweed. Other details as in Fig. 3 
these did not appear to reflect species degradation rates or C:N ratios. Most interestingly, detritivore community composition did not differ between kelp species, and we found no evidence that the presence of detritivores affected rates of kelp degradation or nutritional or chemical content.

We did not identify any differences in wrack biomass between habitats, but biomass was generally lower at our sandy sites, with slightly later but longer winter peaks of wrack accumulation, than on the pebble shores. Although speculative, this may indicate longer residency times of beach-cast wrack on sandy shores that may increase the potential for burial of kelp-derived detritus and add to the capacity of sandy shores for carbon sequestration (KrauseJensen \& Duarte 2016, Krause-Jensen et al. 2018). Experiments are now needed in which residency times and rates of burial and degradation within softsediment habitats of wrack are investigated.

We also identified peak wrack biomass in spring where it was noted that most wrack consisted primarily of old blades of Laminaria hyperborea, which exhibits a discrete phase of detrital production during the months of March-May when the old lamina is shed (Kain 1979, Pessarrodona et al. 2018, 2019). This detritus is then deposited on intertidal beaches (Bustamante et al. 1995, Barreiro et al. 2011), is transported to off-shore habitats, or sinks to the benthos, based on prevailing wind direction and local hydrographic conditions (Filbee-Dexter \& Scheibling 2016, Filbee-Dexter et al. 2018). As monthly mean wave height and wind speed were relatively low in April/May 2017, it is likely that the notable peak in wrack biomass originated from nearby L. hyperborea populations, following the annual pulse in detritus generation. It was also noted that the peak in wrack biomass identified in autumn/early winter (i.e. September-December) comprised a more diverse macroalgal composition and corroborates previous studies in other regions that reported high rates of detritus accumulation following periods of heavy wave action (Orr et al. 2005, Filbee-Dexter \& Scheibling 2012, Gómez et al. 2013). The NE Atlantic typically experiences strong south-westerly gales during autumn and winter (Woolf et al. 2002), which increases the likelihood of full or partial dislodgement of kelp thalli (Smale \& Vance 2016, Pessarrodona et al. 2018). Senescence of annual species such as Saccorhiza polyschides also occurs in late summer, thereby increasing detrital supply during this period (Fernández 2011). A combination of seasonal variability in physical factors and life-history traits of different kelp species are therefore the most likely driv- ers of the temporal patterns of accumulation identified on these shores.

We found that different species of kelp degraded at different rates and identified differences in C:N ratios among species. Species that degraded the most and lost the most biomass had the lowest $\mathrm{C}: \mathrm{N}$ ratios, following previous studies involving terrestrial and aquatic detritus (García-Palacios et al. 2016), including kelps (L. hyperborea, L. groenlandica, Agarum fibriatum and Alaria marginata; Duggins \& Eckman 1997, Norderhaug et al. 2003, 2006). As C:N ratios were not measured prior to degradation in this study, it is difficult to distinguish between whether differences in $\mathrm{C}: \mathrm{N}$ ratios explain differences in degradation rates among species or whether the observed differences were a response to differences in rates of degradation. However, previously published data regarding seasonal variation in the chemical composition of dominant kelp species in the UK show that, for the same time of year (September/October), the $\mathrm{C}: \mathrm{N}$ ratio of fresh kelps follows the same ranking as degraded kelp identified in the current study ( $L$. hyperborea $>$ S. latissima $>$ L. digitata; Schiener et al. 2015). It is likely, therefore, that nutritional content may play a key role in driving rates of degradation.

The degradation process is characterised by an initial phase of rapid mass loss, caused by desiccation and cell lysis associated leaching of soluble compounds, with most mass lost in the first $3 \mathrm{~d}$ after deposition (Garrido et al. 2008, Lastra et al. 2014, 2015, Gladstone-Gallagher et al. 2016). Microbial colonisation then decreases the $\mathrm{C}: \mathrm{N}$ ratio through the breakdown of refractory carbon and nitrogen fixation, facilitating consumption by detritivores (Mews et al. 2006, Dethier et al. 2014). We identified little comparable difference when comparing mass loss between species as a function of wet biomass. Converted to dry mass, however, there were clear patterns between species, highlighting the differences in water content and labile carbohydrates between kelp species and the importance of the initial desiccation period in concentrating the organic matter in a given volume of wrack (Gladstone-Gallagher et al. 2016).

In contrast to previous studies (e.g. Norderhaug et al. 2003, 2006, Mews et al. 2006, Dethier et al. 2014), our results suggest that degradation rates are not driven by levels of polyphenolic concentrations in these kelp species. Similar results have been identified for other kelp species (Saccharina subsimplex and Agarum fimbriatum) and may be a result of using large fragments or whole blades of kelp instead of particulate organic matter that may be 
more vulnerable to leaching and microbial colonisation (Sosik \& Simenstad 2013). The polyphenol content of laminarian kelps is also relatively low compared with some other macroalgal species (e.g. fucoids) and may not be sufficient to prevent microbial colonisation in the first instance (Van Alstyne et al. 1999). It is important to note, however, that the chemical and nutritional content of macroalgae varies seasonally following growth and reproduction cycles and the relationships identified here will likely differ between seasons (Dunton \& Schell 1986, Sjøtun et al. 1996, Gevaert et al. 2001, Schiener et al. 2015). For example, if C:N ratios drive degradation rates of kelps, we would expect slower rates of degradation during spring when carbon assimilation is high but faster rates in winter when nitrogen uptake is greater (Gevaert et al. 2001). In addition, the current study only measured total polyphenolic content and did not differentiate between different types of polyphenolic compounds that may differentially affect decomposition, such as phlorotannins (Van Alstyne et al. 1999).

In our model system, the presence of macroinvertebrate detritivores did not facilitate kelp degradation or alter the nutritional and chemical content of the wrack, in direct contrast to other well-studied systems (Barajas-Guzmán \& Alvarez-Sánchez 2003, Stockley et al. 2009) including other macroalgal species (Jedrzejczak 2002, Dye 2006). It is possible that preferential consumption of heavily degraded material by macrofauna may inhibit degradation by reducing microbial populations (Dye 2006). In a system where wrack provides protection from predators in addition to a food source, this strategy of slowing the degradation process may be beneficial to these detritivores by lengthening the availability of shelter.

Colonisation of macroalgal wrack involves early and late stage colonisers that differ in their nutritional and habitat requirements (Ruiz-Delgado et al. 2015). Amphipods are generally accepted as the primary colonisers that recruit to freshly deposited wrack to forage in high densities, followed by dipteran flies and coleopteran beetles that do not consume kelp directly but aid in degradation through the spread of microorganisms via feeding and burrowing activities (Colombini \& Chelazzi 2003, Gómez et al. 2013, Rodil et al. 2015). Colonisation by herbivorous and carnivorous beetles (Staphylinidae, Hydrophilidae and Ptilidae) closely follows colonisation by amphipods and dipteran larvae, which use the abundant food source within the wrack (Jedrzejczak 2002, Colombini \& Chelazzi 2003, Garrido et al. 2008, Colombini et al. 2009). This temporal succes- sion of assemblage composition could explain the lack of differences identified in invertebrate assemblages associated with different kelp species as the communities sampled may have reached 'climax' after a 4 wk period. Previous studies have reported variation in detritivore assemblage composition in space and time, with clear patterns within the first $3 \mathrm{~d}$ of degradation during the initial leaching phase that diminish after Day 7 (Garrido et al. 2008, Rodil et al. 2015). It is possible that if sampled periodically throughout the experimental duration, community composition may have differed between kelp species, and detritivores may have had a greater effect on rates of degradation.

It is important to note, however, that there is potential for the lack of detritivore effects to be an experimental artefact of the access treatment design. Naturally, no barrier would exist between detritivores and the colonisation of wrack. Although total densities in access treatments exceeded more than 100 individuals per bag in all treatments, sometimes more than 200, the density of detritivores found in naturally deposited wrack was not quantified. It is possible that the experimental design inhibited detritivore colonisation, and natural detritivore densities may be much greater than densities accumulated within the bags. Bag densities may therefore not have been great enough to induce a significant detritivore effect. It should be noted, however, that exclusion treatments were very effective, and on average, $<1$ individual detritivore was found in each bag. Given that, comparably, access treatments had high densities of detritivores, it is likely that we should have seen an effect if the detritivores had played a key role.

Detrital pathways in marine ecosystems remain unresolved despite playing a critical role in ecosystem functioning (Queirós et al. 2019, Legge et al. 2020), which has led to a recent surge in interest as we attempt to incorporate new data into refined marine ecosystem models (Docmac et al. 2017, Elliott Smith et al. 2018, Wernberg \& Filbee-Dexter 2018, Filbee-Dexter et al. 2020, Pedersen et al. 2020). Here we show that resource deposition via wrack does not differ between habitats but varies throughout the year, most likely owing to differences in the functional traits of nearby macroalgal source communities and prevailing weather conditions. We identified an element of temporal predictability in wrack deposition that can be incorporated into ecosystem models, particularly those aimed at modelling coastal carbon fluxes. Quantitative studies are now needed to identify species-specific contributions to wrack bio- 
mass, and an effort must be made to link this production to source populations and habitats. In contrast to previous studies, we found no evidence of detritivores determining rates of wrack degradation, which highlights the importance of microbial communities and the role they play in coastal carbon and nutrient cycling. This may be particularly important when measuring ecosystem processes at the community level, as many studies do not incorporate the effects of microbial diversity. Lastly, the differences in rates of degradation among kelp species that differ in their nutritional and chemical content show the importance of species-specific traits in determining rates of nutrient and carbon cycling. Predicted large-scale community reconfiguration in which warm-temperate kelps, that differ in species-specific traits in comparison to cold-temperate kelps, are expected to expand their range may have significant effects on coastal ecosystem functioning (Pessarrodona et al. 2019). Given the high level of connectivity across systems, predicted and observed impacts of climate change and other anthropogenic stressors on these source populations are likely to significantly alter ecosystem functioning in recipient communities and habitats.

Data availability. All data are available from the British Oceanographic Data Centre.

Acknowledgements. We thank Dr. Lydia White, Conn Murray, Brian McElwaine, Dr. Camilla Bertolini and Dr. Lawrence Eagling for their invaluable help in the field and laboratory. We also thank Professor Mark Emmerson for his experimental advice and guidance. This study was completed as part of a PhD studentship funded by the Department for Economy Northern Ireland and in part by the Natural Environmental Research Council and the Department for Environment, Food and Rural Affairs (grant number NE/L003279/1, Marine Ecosystem Research Programme). D.A.S. was supported by a UKRI Future Leaders Fellowship (MR/S032827/1).

\section{LITERATURE CITED}

Barajas-Guzmán G, Alvarez-Sánchez J (2003) The relationships between litter fauna and rates of litter decomposition in a tropical rain forest. Appl Soil Ecol 24:91-100

Barnes AD, Jochum M, Lefcheck JS, Eisenhauer N and others (2018) Energy flux: the link between multitrophic biodiversity and ecosystem functioning. Trends Ecol Evol 33:186-197

Barreiro F, Gómez M, Lastra M, López J, de la Huz R (2011) Annual cycle of wrack supply to sandy beaches: effect of the physical environment. Mar Ecol Prog Ser 433:65-74

Bennett S, Wernberg T, Connell SD, Hobday AJ, Johnson CR, Poloczanska ES (2016) The 'Great Southern Reef': social, ecological and economic value of Australia's neglected kelp forests. Mar Freshw Res 67:47-56
Blamey LK, Bolton JJ (2018) The economic value of South African kelp forests and temperate reefs: past, present and future. J Mar Syst 188:172-181

* Britton-Simmons KH, Rhoades AL, Pacunski RE, Galloway AWE and others (2012) Habitat and bathymetry influence the landscape-scale distribution and abundance of drift macrophytes and associated invertebrates. Limnol Oceanogr 57:176-184

* Bruder A, Schindler MH, Moretti MS, Gessner MO (2014) Litter decomposition in a temperate and a tropical stream: the effects of species mixing, litter quality and shredders. Freshw Biol 59:438-449

* Bustamante RH, Branch GM, Eekhout S (1995) Maintenance of an exceptional intertidal grazer biomass in South Africa: subsidy by subtidal kelps. Ecology 76: 2314-2329

Clarke KR, Gorley RN (2015) Getting started with PRIMER v7. PRIMER-E, Plymouth

Clarke KR, Gorley RN, Somerfield PJ, Warwick RM (2014) Change in marine communities: an approach to statistical analysis and interpretation, $3^{\text {rd }}$ edn. PRIMER-E, Plymouth

Colombini I, Chelazzi L (2003) Influence of marine allochthonous input on sandy beach communities. Oceanogr Mar Biol Annu Rev 41:115-159

Colombini I, Mateo MÁ, Serrano O, Fallaci M, Gagnarli E, Serrano L, Chelazzi L (2009) On the role of Posidonia oceanica beach wrack for macroinvertebrates of a Tyrrhenian sandy shore. Acta Oecol 35:32-44

Cooper JAG, Jackson DWT, Navas F, McKenna J, Malvarez G (2004) Identifying storm impacts on an embayed, highenergy coastline: examples from western Ireland. Mar Geol 210:261-280

* Dangles O, Malmqvist B (2004) Species richness-decomposition relationships depend on species dominance. Ecol Lett 7:395-402

NDethier MN, Brown AS, Burgess S, Eisenlord ME and others (2014) Degrading detritus: Changes in food quality of aging kelp tissue varies with species. J Exp Mar Biol Ecol 460:72-79

* Docmac F, Araya M, Hinojosa IA, Dorador C, Harrod C (2017) Habitat coupling writ large: Pelagic-derived materials fuel benthivorous macroalgal reef fishes in an upwelling zone. Ecology 98:2267-2272

* Dugan JE, Hubbard DM, McCrary MD, Pierson MO (2003) The response of macrofauna communities and shorebirds to macrophyte wrack subsidies on exposed sandy beaches of southern California. Estuar Coast Shelf Sci 58:25-40

* Duggins DO, Eckman JE (1997) Is kelp detritus a good food for suspension feeders? Effects of kelp species, age and secondary metabolites. Mar Biol 128:489-495

* Dunton KH, Schell DM (1986) Seasonal carbon budget and growth of Laminaria solidungula in the Alaskan High Arctic. Mar Ecol Prog Ser 31:57-66

Dye AH (2006) Inhibition of the decomposition of Zostera capricornii litter by macrobenthos and meiobenthos in a brackish coastal lake system. Estuaries Coasts 29: 802-809

Eleftheriou A, Holme NA (1984) Macrofauna techniques. In: Holm NA, McIntyre AD (eds) Methods for the study of marine benthos. Blackwell Scientific, Oxford, p 140-216

Elliott Smith EA, Harrod C, Newsome SD (2018) The importance of kelp to an intertidal ecosystem varies by trophic level: insights from amino acid $\delta^{13} \mathrm{C}$ analysis. Ecosphere 9:e02516 
Epstein G, Foggo A, Smale DA (2019) Inconspicuous impacts: Widespread marine invader causes subtle but significant changes in native macroalgal assemblages. Ecosphere 10:e02814

Fernández C (2011) The retreat of large brown seaweeds on the north coast of Spain: the case of Saccorhiza polyschides. Eur J Phycol 46:352-360

Filbee-Dexter K, Scheibling RE (2012) Hurricane-mediated defoliation of kelp beds and pulsed delivery of kelp detritus to offshore sedimentary habitats. Mar Ecol Prog Ser 455:51-64

Filbee-Dexter K, Scheibling RE (2016) Spatial patterns and predictors of drift algal subsidy in deep subtidal environments. Estuaries Coasts 39:1724-1734

Filbee-Dexter K, Wernberg T, Norderhaug KM, RamirezLlodra E, Pedersen MF (2018) Movement of pulsed resource subsidies from kelp forests to deep fjords. Oecologia 187:291-304

Filbee-Dexter K, Wernberg T, Fredriksen S, Norderhaug KM, Pedersen MF (2019) Arctic kelp forests: diversity, resilience and future. Global Planet Change 172:1-14

* Filbee-Dexter K, Pedersen MF, Fredriksen S, Norderhaug $\mathrm{KM}$ and others (2020) Carbon export is facilitated by sea urchins transforming kelp detritus. Oecologia 192: 213-225

Fox J, Weisberg S (2011) An R companion to applied regression, $2^{\text {nd }}$ edn. Sage Publications, Thousand Oaks, CA

* García-Palacios P, McKie BG, Handa IT, Frainer A, Hättenschwiler S (2016) The importance of litter traits and decomposers for litter decomposition: a comparison of aquatic and terrestrial ecosystems within and across biomes. Funct Ecol 30:819-829

Garrido J, Olabarria C, Lastra M (2008) Colonization of wrack by beetles (Insecta, Coleoptera) on a sandy beach of the Atlantic coast. Vie Milieu 58:223-232

* Gevaert F, Davoult D, Creach A, Kling R, Janquin MA, Seuront L, Lemoine Y (2001) Carbon and nitrogen content of Laminaria saccharina in the eastern English Channel: biometrics and seasonal variations. J Mar Biol Assoc UK 81:727-734

* Gilson AR, Smale DA, O'Connor N (2021) Ocean warming and species range shifts affect rates of ecosystem functioning by altering consumer-resource interactions. Ecology 102:e03341

Gladstone-Gallagher RV, Lohrer AM, Lundquist CJ, Pilditch CA (2016) Effects of detrital subsidies on soft-sediment ecosystem function are transient and source-dependent. PLOS ONE 11:e0154790

Godbold JA, Solan M, Killham K (2009) Consumer and resource diversity effects on marine macroalgal decomposition. Oikos 118:77-86

Gómez M, Barreiro F, López J, Lastra M, de la Huz R (2013) Deposition patterns of algal wrack species on estuarine beaches. Aquat Bot 105:25-33

* Harrison XA, Donaldson L, Correa-Cano ME, Evans J and others (2018) A brief introduction to mixed effects modelling and multi-model inference in ecology. PeerJ 6:e4794

Hori M (2008) Between-habitat interactions in coastal ecosystems: current knowledge and future challenges for understanding community dynamics. Plankton Benthos Res 3:53-63

Hyndes GA, Lavery PS, Doropoulos C (2012) Dual processes for cross-boundary subsidies: incorporation of nutrients from reef-derived kelp into a seagrass ecosystem. Mar Ecol Prog Ser 445:97-107
Jedrzejczak MF (2002) Stranded Zostera marina L. vs wrack fauna community interactions on a Baltic sandy beach (Hel, Poland): a short-term pilot study. Part 2. Driftline effects of succession changes and colonisation of beach fauna. Oceanologia 44:367-387

Kain JM (1979) A view of the genus Laminaria. Oceanogr Mar Biol Annu Rev 17:101-161

Kominoski JS, Hoellein TJ, Leroy CJ, Pringle CM, Swan CM (2010) Beyond species richness: expanding biodiversity-ecosystem functioning theory in detritus-based streams. River Res Appl 26:67-75

Krause-Jensen D, Duarte CM (2016) Substantial role of macroalgae in marine carbon sequestration. Nat Geosci 9:737-742

K Krause-Jensen D, Lavery P, Serrano O, Marbà N, Masque P, Duarte CM (2018) Sequestration of macroalgal carbon: the elephant in the Blue Carbon room. Biol Lett 14: 20180236

Krumhansl KA, Scheibling RE (2012b) Production and fate of kelp detritus. Mar Ecol Prog Ser 467:281-302

* Lastra M, Rodil IF, Sánchez-Mata A, García-Gallego M, Mora J (2014) Fate and processing of macroalgal wrack subsidies in beaches of Deception Island, Antarctic Peninsula. J Sea Res 88:1-10

* Lastra M, López J, Neves G (2015) Algal decay, temperature and body size influencing trophic behaviour of wrack consumers in sandy beaches. Mar Biol 162:221-233

Legge O, Johnson M, Hicks N, Jickells T and others (2020) Carbon on the Northwest European Shelf: contemporary budget and future influences. Front Mar Sci 7:143

Lenth RV (2018) Least-squares means: the R package lsmeans. J Stat Softw 69:1-33

Little CJ, Altermatt F (2018) Species turnover and invasion of dominant freshwater invertebrates alter biodiversityecosystem-function relationship. Ecol Monogr 88:461-480

LLoreau M (2001) Biodiversity and ecosystem functioning: current knowledge and future challenges. Science 294: 804-808

ㄴoreau M, Mouquet N, Holt RD (2003) Meta-ecosystems: a theoretical framework for a spatial ecosystem ecology. Ecol Lett 6:673-679

Karleau JN, Guichard F, Mallard F, Loreau M (2010) Nutrient flows between ecosystems can destabilize simple food chains. J Theor Biol 266:162-174

*Mews M, Zimmer M, Jelinski DE (2006) Species-specific decomposition rates of beach-cast wrack in Barkley Sound, British Columbia, Canada. Mar Ecol Prog Ser 328:155-160

Moore JC, Berlow EL, Coleman DC, de Ruiter PC and others (2004) Detritus, trophic dynamics and biodiversity. Ecol Lett 7:584-600

Newell SY, Fallon RD, Cal Rodriguez RM, Groene LC (1985) Influence of rain, tidal wetting and relative humidity on release of carbon dioxide by standing-dead salt-marsh plants. Oecologia 68:73-79

*Norderhaug KM, Fredriksen S, Nygaard K (2003) Trophic importance of Laminaria hyperborea to kelp forest consumers and the importance of bacterial degradation to food quality. Mar Ecol Prog Ser 255:135-144

* Norderhaug KM, Nygaard K, Fredriksen S (2006) Importance of phlorotannin content and C:N ratio of Laminaria hyperborea in determining its palatability as food for consumers. Mar Biol Res 2:367-371

O'Connor MO, Cooper JAG, Jackson DWT (2007) Morphological behaviour of headland-embayment and inlet- 
associated beaches, Northwest Ireland. J Coast Res Spec Issue 50:626-630

Orr M, Zimmer M, Jelinski DE, Mews M (2005) Wrack deposition on different beach types: spatial and temporal variation in the pattern of subsidy. Ecology 86:1496-1507

Pedersen MF, Filbee-Dexter K, Norderhaug KM, Fredriksen S, Frisk NL, Fagerli CW, Wernberg T (2020) Detrital carbon production and export in high latitude kelp forests. Oecologia 192:227-239

Pessarrodona A, Moore PJ, Sayer MDJ, Smale DA (2018) Carbon assimilation and transfer through kelp forests in the NE Atlantic is diminished under a warmer ocean climate. Glob Change Biol 24:4386-4398

Pessarrodona A, Foggo A, Smale DA (2019) Can ecosystem functioning be maintained despite climate-driven shifts in species composition? Insights from novel marine forests. J Ecol 107:91-104

Polis GA, Anderson WB, Holt RD (1997) Toward an integration of landscape and food web ecology: the dynamics of spatially subsidized food webs. Annu Rev Ecol Syst 28: 289-316

Queirós AM, Stephens N, Widdicombe S, Tait K and others (2019) Connected macroalgal-sediment systems: blue carbon and food webs in the deep coastal ocean. Ecol Monogr 89:e01366

R Development Core Team (2017) R: A language and environment for statistical computing. R Foundation for Statistical Computing, Vienna. https://www.R-project.org/

Raffaelli D, Emmerson M, Solan M, Biles C, Paterson D (2003) Biodiversity and ecosystem processes in shallow coastal waters: an experimental approach. J Sea Res 49: 133-141

Rodil IF, Lucena-Moya P, Olabarria C, Arenas F (2015) Alteration of macroalgal subsidies by climate-associated stressors affects behavior of wrack-reliant beach consumers. Ecosystems 18:428-440

Ruiz-Delgado MC, Reyes-Martínez MJ, Sánchez-Moyano JE, López-Pérez J, García-García FJ (2015) Distribution patterns of supralittoral arthropods: wrack deposits as a source of food and refuge on exposed sandy beaches (SW Spain). Hydrobiologia 742:205-219

Schiener P, Black KD, Stanley MS, Green DH (2015) The seasonal variation in the chemical composition of the kelp species Laminaria digitata, Laminaria hyperborea, Saccharina latissima and Alaria esculenta. J Appl Phycol 27:363-373

Schoenrock KM, Chan KM, O'Callaghan T, O'Callaghan R, Golden A, Krueger-Hadfield SA, Power AM (2020) A review of subtidal kelp forests in Ireland: from first descriptions to new habitat monitoring techniques. Ecol Evol 10:6819-6832

Sjøtun K, Fredriksen S, Rueness J (1996) Seasonal growth and carbon and nitrogen content in canopy and first-year plants of Laminaria hyperborea (Laminariales, Phaeophyceae). Phycologia 35:1-8
Smale DA, Vance T (2016) Climate-driven shifts in species' distributions may exacerbate the impacts of storm disturbances on North-east Atlantic kelp forests. Mar Freshw Res 67:65-74

Smale DA, Burrows MT, Moore P, O'Connor N, Hawkins SJ (2013) Threats and knowledge gaps for ecosystem services provided by kelp forests: a northeast Atlantic perspective. Ecol Evol 3:4016-4038

* Sosik EA, Simenstad CA (2013) Isotopic evidence and consequences of the role of microbes in macroalgae detritusbased food webs. Mar Ecol Prog Ser 494:107-119

* Ståhlberg C, Bastviken D, Svensson BH, Rahm L (2006) Mineralisation of organic matter in coastal sediments at different frequency and duration of resuspension. Estuar Coast Shelf Sci 70:317-325

* Stévant P, Marfaing H, Rustad T, Sandbakken I, Fleurence J, Chapman A (2017) Nutritional value of the kelps Alaria esculenta and Saccharina latissima and effects of short-term storage on biomass quality. J Appl Phycol 29: 2417-2426

Stockley RA, Oxford GS, Ormond RFG (2009) Do invertebrates matter? Detrital processing in the River SwaleOuse. Sci Total Environ 210:427-435

Teagle H, Hawkins SJ, Moore PJ, Smale DA (2017) The role of kelp species as biogenic habitat formers in coastal marine ecosystems. J Exp Mar Biol Ecol 492:81-98

* Tilman D, Isbell F, Cowles JM (2014) Biodiversity and ecosystem functioning. Annu Rev Ecol Evol Syst 45: 471-493

* Van Alstyne KL, McCarthy JJ, Hustead CL, Kearns LJ (1999) Phlorotannin allocation among tissues of Northeastern Pacific kelps and rockweeds. J Phycol 35: 483-492

Vanderklift MA, Wernberg T (2008) Detached kelps from distant sources are a food subsidy for sea urchins. Oecologia 157:327-335

Waterhouse AL (2001) Determination of total phenolics. In: Wrolstad RE (ed) Current protocols in food analytical chemistry, Vol 11. John Wiley \& Sons, New York, NY, p 1.1.1-1.1.8

WWernberg T, Filbee-Dexter K (2018) Grazers extend blue carbon transfer by slowing sinking speeds of kelp detritus. Sci Rep 8:17180

Wernberg T, Vanderklift MA, How J, Lavery PS (2006) Export of detached macroalgae from reefs to adjacent seagrass beds. Oecologia 147:692-701

Woodward G (2009) Biodiversity, ecosystem functioning and food webs in fresh waters: assembling the jigsaw puzzle. Freshw Biol 54:2171-2187

Woolf DK, Challenor PG, Cotton PD (2002) Variability and predictability of the North Atlantic wave climate. J Geophys Res Oceans 107:3145

Zuur AF, Ieno EN, Walker N, Saveliev AA, Smith GM (2009) Mixed effects models and extensions in ecology with R. Springer, New York, NY 
Appendix. Additional information on the means and standard deviations for mass loss $\left(\mathrm{g} \mathrm{d}^{-1}\right)$, C:N ratios and polyphenol concentrations (\%) for Laminaria hyperborea, L. digitata, Saccharina latissima, Saccorhiza polyschides and a polyculture of all kelp species

Table A1. Mean (SD) mass loss $\left(\mathrm{g} \mathrm{d}^{-1}\right)$, C:N ratio and polyphenol concentration (\%) for each level of kelp species after a 4 wk degradation period at 2 pebble shores (Ballywhoriskey and Glassaugh Bay) in Co. Donegal, Ireland. (-) indicates variables that were not measured for the polyculture

\begin{tabular}{|lcccccc|}
\hline \multirow{2}{*}{ Species } & \multicolumn{2}{c}{ Mass loss $\left(\mathrm{g} \mathrm{d}^{-1}\right)$} & \multicolumn{2}{c|}{ C:N ratio } & \multicolumn{2}{c|}{$\begin{array}{c}\text { Polyphenol concentration (\%) } \\
\text { Access }\end{array}$} \\
& Access & Exclusion & Access & Exclusion & Aclusion \\
\hline Laminaria hyperborea & $2.04(0.68)$ & $1.81(0.49)$ & $37.18(12.9)$ & $42.84(21.9)$ & $0.020(0.01)$ & $0.024(0.02)$ \\
Laminaria digitata & $4.27(0.63)$ & $4.21(0.62)$ & $20.4(7.4)$ & $21.6(7.4)$ & $0.020(0.2)$ & $0.024(0.1)$ \\
Saccharina latissima & $2.54(0.35)$ & $2.57(0.39)$ & $26.15(7.4)$ & $32.94(10.2)$ & $0.016(0.1)$ & $0.020(0.2)$ \\
Saccorhiza polyschides & $2.13(0.24)$ & $2.09(0.24)$ & $26.34(7.8)$ & $25.13(6.9)$ & $0.018(0.02)$ & $0.015(0.01)$ \\
Polyculture & $3.01(0.45)$ & $2.75(0.54)$ & - & - & - & - \\
\hline
\end{tabular}

Editorial responsibility: Emily Carrington,

Friday Harbor, Washington, USA

Reviewed by: 3 anonymous referees
Submitted: December 3, 2020

Accepted: July 9, 2021

Proofs received from author(s): September 7, 2021 